Psychology of Language and Communication 2017, Vol. 21, No. 1

DE GRUYTER

OPEN

DOI: $10.1515 /$ plc-2017-0001

MICHAL BILEWICZ, ANNA STEFANIAK, MARTA WITKOWSKA, KAROLINA HANSEN

Faculty of Psychology, University of Warsaw

\title{
LANGUAGE OF RESPONSIBILITY. THE INFLUENCE OF LINGUISTIC ABSTRACTION ON COLLECTIVE MORAL EMOTIONS
}

\begin{abstract}
Two experiments investigated the effects of linguistic abstractness on the experience of collective moral emotions. In Experiment 1 participants were presented with two scenarios about ingroup misbehavior, phrased using descriptive action verbs, interpretative action verbs, adjectives or nouns. The results show that participants experienced slightly more negative moral emotions with higher levels of linguistic abstractness. In Experiment 2 we also tested for the influence of national identification on the relationship between linguistic abstractness and emotional reactions. Additionally, we expanded the number of scenarios. Experiment 2 replicated the earlier pattern, but found larger differences between conditions. The strength of national identification did not moderate the observed effects. The results of this research are discussed within the context of the linguistic category model and psychology of collective moral emotions.
\end{abstract}

Key words: linguistic abstractness, Linguistic Category Model, collective emotions, national identification

\section{Introduction}

"In 1915 the Ottoman Government ordered that the Armenian population residing in or near the war zone should be relocated to the southern Ottoman provinces" (Center For Eurasian Studies Ankara, 2016). This is a description of the tragic events that happened a century ago provided on the website of the Turkish Ministry of Foreign Affairs. Although the statement is true, it does not convey any information about the harm caused by this decision, about the suffering of the Armenian victims, or about the genocidal aspects

Address for correspondence: Michal Bilewicz, Faculty of Psychology, University of Warsaw, Stawki 5/7, 00-183 Warszawa, Poland. Tel +48 2255498 42. E-mail: bilewicz@psych.uw.edu.pl 
of the relocation policy. Therefore, it is unlikely to elicit the moral emotions of shame, guilt or regret among contemporary Turks.

When describing historical events, people make choices regarding the formal aspects of such descriptions. They might, for instance, explain cruel acts by emphasizing situational causes, thereby decreasing the collective responsibility of the perpetrators (Bilewicz, Witkowska, Stefaniak, \& Imhoff, submitted; Doosje \& Branscombe, 2003). Here, we propose that even the grammatical form used in such descriptions might increase or limit the moral emotions stimulated by information about the negative actions of fellow ingroup members.

People's actions can be described on different levels of abstraction. The same action can be identified on a higher, more abstract level (e.g. "riding a bicycle") or on a low, more specific level (e.g. "pushing pedal with a foot"; Vallacher \& Wegner, 1987). Such levels of abstractness can also be identified by the grammatical choices that people make: verbs are considered to be more concrete grammatical terms, whereas adjectives and nouns are considered more abstract - as they convey information not only about the action itself, but also about the dispositions of an actor, predictability and stability of the action, etc. According to the (LCM, Semin, 2011; Semin \& Fiedler, 1988, 1991), particular features of the linguistic forms used to describe people's behavior can lead to distinctive inferences about the behavior itself and about the nature of individuals and groups. Specifically, the model suggests that higher levels of linguistic abstractness are associated with more internal and dispositional inferences. The usage of a more concrete language (e.g., a descriptive action verb "the government ordered that the Armenians should be relocated") would lead to a less dispositional attribution than the use of a more abstract language (e.g., an interpretative action verb: "the government harmed the Armenians", or an adjective: "the government was cruel to the Armenians"). Collective moral emotions of guilt and shame stem from self-categorization as a member of the perpetrator group, as well as dispositional attribution of a controllable behavior of fellow ingroup members that results in negative outcomes for an outgroup (Lickel, Schmader, \& Spanovic, 2007; Wohl, Branscombe, \& Klar, 2006). Based on this, we expect that higher linguistic abstractness of a description of an event should elicit more collective moral emotions.

\section{Linguistic Category Model and Language of Responsibility}

Language can express different levels of personal and collective responsibility. LCM research has found that with increasing linguistic abstractness both the perceived controllability of the behavior and the tendency to make dispositional inferences about the actor increase (Semin \& Fiedler, 1991). According to the original version of the model, linguistic abstraction is expressed by different forms of verbs and adjectives. Descriptive action verbs (DAV) represent the most concrete form of description - they encode the behavior as objectively as possible. The meaning of the behavior described by DAV 
is dependent on social and situational context. Interpretative action verbs (IAV) are more abstract linguistic forms that involve interpretation beyond the description, as well as positive or negative evaluation of the action. State verbs (SV) refer to the emotional states that an action causes in its recipients, whereas adjectives (ADJ) suggest a long-lasting disposition of the agents. Further research on linguistic abstraction (Carnaghi et al., 2008; Graf, Bilewicz, Finell, \& Geschke, 2013; Walton \& Banaji, 2004) extended the model by showing that nouns (NOUN) represent the most abstract linguistic form, having the highest inductive potential and implying a high level of essentialism.

Because of the internal attribution associated with highly abstract grammatical forms, linguistic abstraction conveys important information about responsibility. Janoff-Bullman, Sheikh, and Hepp (2009) showed that when conveying information about proscriptive morality (with negative outcomes, inhibition focused), people use more concrete language and avoid highly abstract utterances. An analysis of Nuremberg trials protocols found that the defense attorneys used more concrete linguistic forms, whereas the prosecutors tended to use more abstract ones (i.e. IAV) when describing the intentions and responsibility of the war criminals (Schmid \& Fiedler, 1996). Furthermore, when comparing peace-time trial speeches, Schmid and Fiedler (1996) found that prosecutors use more abstract language (IAV) when talking about the negative actions of the defendant, whereas defense attorneys use such abstract language when talking about positive actions. A similar phenomenon was also observed at a collective level(Maass, Salvi,Arcuri, \& Semin, 1989). For example, non-Jewish Italian press reporting an antisemitic incident during a basketball game used significantly more concrete linguistic forms than a Jewish-Italian newspaper writing about the same incident. A similar bias was observed in an Italian TV report about negative actions of Italian and Iraqi troops during the first Gulf War (Maass, Corvino, \& Arcuri, 1994). This evidence suggests that decreased levels of abstractness could constitute a strategy for denying ingroup responsibility for negative acts and for the downregulation of negative collective moral emotions.

\section{The Present Research: Linguistic Abstractness and Negative Moral Emotions}

The existing research on linguistic abstractness analyzed the judgments of responsibility and attributions among outside observers (Schmid \& Fiedler, 1996, 1998), but not the emotions experienced by the actors or their fellow ingroup members. Negative moral emotions, such as shame, guilt, anger, or regret can be experienced not only on the individual level, but also by association with group members who committed immoral acts (Doosje, Branscombe, Spears, $\&$ Manstead, 1998). The prerequisite to feel such emotion is an internal attribution of collective responsibility among group members, and is part of self-categorization as a member of a perpetrator group (Lickel, et al., 2007; Wohl et al., 2006). This might be the reason why collective moral emotions are so rare and in most 
cases (particularly when the negative incidents are presented in a relatively concrete way) are hard to elicit (Klar \& Branscombe, 2016; Leach, Zeinnedine, \& Cehajic-Clancy, 2013). Therefore, it could be expected that high linguistic abstraction of information about ingroup members' misbehavior would lead to a greater expression of negative collective emotions about such misbehavior.

In the present research we aimed to test whether the increased linguistic abstraction of a statement about negative intergroup events will heighten the intensity of collective moral emotions. In two experiments, we presented participants with a set of scenarios in which ingroup members misbehaved toward outgroup members. The scenarios were described with either highly concrete (DAV), concrete (IAV), abstract (ADJ) or highly abstract (NOUN) grammatical forms, according to the LCM and its extensions. Due to the fact that SV are processed differently in the Polish language as compared to Western languages (they seem to be processed as paradoxically less abstract than IAV's; Kwiatkowska, 2013), we decided to omit this linguistic category from our research.

Participants were then asked to rate the intensity of the negative emotions that they experienced after reading each scenario. In Experiment 1, we expected that higher levels of linguistic abstractness would elicit more intense expressions of negative moral emotions. As literature on collective emotions (Branscombe \& Miron, 2004; Klein, Licata, \& Pierucci, 2011; Roccas, Klar, \& Liviatan, 2006) demonstrates that identification constitutes one of the important determinants of experiencing collective moral emotions, in Experiment 2 we additionally measured the strength of identification as a potential moderator of the experience of negative emotions. We expected that people with higher levels of identification would generally react to abstract information about their ingroup's misdeeds with higher levels of collective moral emotions ${ }^{1}$. However, we also wanted to investigate whether the type of identification would play a role in these effects. As shown by Roccas and colleagues (2006), glorification of one's nation may lead to less, whereas attachment to more intense collective guilt.

\section{Experiment 1}

The aim of Experiment 1 was to investigate the hypothesis that linguistic abstractness in describing negative actions of ingroup members is related to feelings of collective moral emotions: shame, guilt, anger, and regret. We expected that a greater abstractness of language would elicit more intense negative feelings related to the threatening information about the ingroup.

\footnotetext{
We recognize that the literature makes opposing claims with regard to the influence of the strength of identification on moral emotions. On the one hand (and as we hypothesize in our work) - an individual must be identified with a group to experience any group-based emotions (e.g. Wohl et al., 2006). On the other, people highly identified with their in-group may be more likely to downplay the negative ingroup behavior (e.g. Branscombe \& Miron, 2004 ; Roccas et al., 2006). Therefore the null effects found in the moderation analyses in Experiment 2 could be a result of those opposing processes. This hypothesis cannot be tested with the current data. However, we would like to see it explored in future studies.
} 


\section{Method}

Participants and procedure. We collected data as a part of a larger study ${ }^{2}$ from 162 students of English Philology at the University of Warsaw (40 men, 122 women; $M_{\text {Age }}=20.80, S D_{\text {Age }}=2.01$ ). The experiment followed a betweenparticipants design with one experimental factor (linguistic abstractness) with four levels (DAV, IAV, ADJ, NOUN). Participants were randomly assigned to one of four groups and asked to read two scenarios presenting negative behavior of their compatriots. After each scenario, participants indicated how the story made them feel by indicating to what extent they experienced shame, guilt, anger, and regret.

Manipulation. Each participant read two scenarios. The first scenario presented a man abusing the social welfare system of another country. The second scenario described a case of smuggling cigarettes across the border (see Appendix). In order to insure that the stories we created were perceived as clearly negative as well as reliable, we ran a pretest of our materials on an online students panel $(N=39 ; 4$ men, 34 women; one did not indicate gender, $\left.M_{\text {age }}=25.21, S D_{\text {age }}=3.66\right)$. We asked four questions to each of the stories, all on 1 to 5 Likert-type scales: What image of Poles does this behavior create? (1 - Definitely negative to 5 - Definitely positive); How do you evaluate this behavior in general? (1 - Definitely negatively to 5 - Definitely positively); In your opinion, how far the behavior was fair or unfair? (1 - Definitely unfair to 5 -Definitely fair); In your opinion, does it happen that Poles behave like this abroad? (1 - Definitely not to 5 - Definitely yes). The results revealed that the behaviors in the stories were perceived as creating a negative image of Poles $\left(M_{\text {Scenariol }}=1.46, S D_{\text {Scenario1 }}=0.72 ; M_{\text {Scenario2 }}=2.10, S D_{\text {Scenario2 }}=0.71\right)$, as being negative $\left(M_{\text {Scenario1 }}=1.36, S D_{\text {Scenario1 }}=0.69 ; M_{\text {Scenario2 }}=2.10, S D_{\text {Scenario2 }}=0.72\right)$ and unfair $\left(M_{\text {Scenario1 }}=1.26, S D_{\text {Scenariol }}=0.64 ; M_{\text {Scenario2 }}=1.90, S D_{\text {Scenario2 }}=0.75\right)$, and as happening sometimes $\left(M_{\text {Scenariol }}=3.41, S D_{\text {Scenario1 }}=0.50 ; M_{\text {Scenario2 }}=3.79\right.$, $\left.S D_{\text {Scenario2 }}=0.77\right)$. All means differed significantly from the middle point of the scale $(p s<.001)$.

Measures of collective moral emotions. After reading each scenario, participants were asked to indicate to what extent they experienced shame, guilt, anger, and regret while reading it. All the answers were assessed using an 11-point scale from 0 (I do not experience this emotion at all) to 10 (I experience this emotion to a great extent). The composite score of collective emotions was constructed by averaging all the emotions for each scenario $\left(\alpha_{\text {Scenariol }}=.74\right.$ and $\left.\alpha_{\text {Scenariol }}=.80\right)$.

\footnotetext{
The larger study aimed at testing the salience of national identities on reactions to negative ingroup behavior. Thus, the study also included a manipulation of national identity salience and a measurement of negative behavior attribution, perceived stability over time, and threat. The manipulation did not affect the experience of collective moral emotions, $F(1,161)=0.59, p=.46$; nor did it do so in interaction with linguistic abstractness, $F(3,161)=0.93, p=.43$.
} 


\section{Results}

The main effect of linguistic abstractness on the intensity of collective emotions experienced by participants was not significant for any of the two situations, $F_{\text {Scenario1 }}(3,161)=0.59, p=.62, \eta^{2}=0.01$ and $F_{\text {Scenario } 2}(3,161)=0.82, p=.48$, $\eta^{2}=0.02$. Examining the mean values of intensity of moral emotions for each condition, we observed that the intensity increased gradually as a function of increased linguistic abstractness (see Figure 1). However, this linear trend did not reach the conventional levels of significance; $F_{\text {Scenariol }}(1,161)=1.62$, $p=.21, \eta^{2}=0.01$ and $F_{\text {Scenario2 }}(1,161)=2.22, p=.14, \eta^{2}=0.01$. Further analyses in which these situations were combined showed that the main effect of linguistic abstractness on intensity of collective emotions experienced by participants was not significant, $F(3,161)=0.79, p=.52, \eta^{2}=0.01$. The noticeable linear trend did not reach the conventional levels of significance, $F(1,161)=2.25, p=.14$, $\eta^{2}=0.01$, suggesting however that the intensity of collective emotions might increase gradually as a function of increased linguistic abstractness.

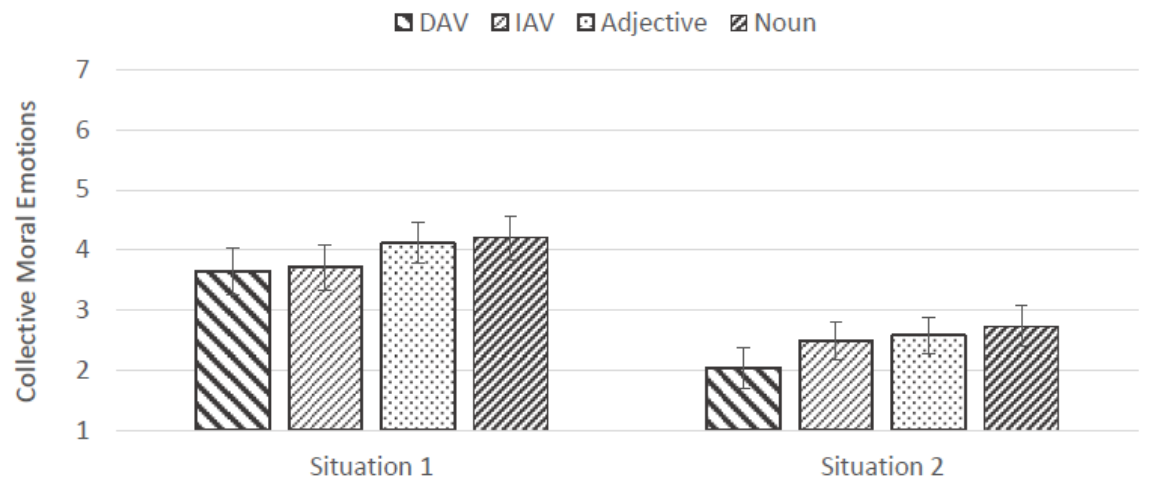

Figure 1. Means of the composite measure of negative collective emotions as a function of the abstractness of the description of negative ingroup behavior (DAV = Descriptive action verb; IAV = Interpretive action verb) across two situations (Situation 1 = abusing social system; Situation 2 = smuggling cigarettes). Error bars represent SEM.

\section{Discussion}

Experiment 1 presents a first attempt at testing how the level of abstractness of the language used to describe misbehavior of one's ingroup members influences the intensity of emotional responses. We observed more intense emotional reactions (i.e. higher levels of collective anger, guilt, shame, and regret) to more abstract depictions of one's compatriots' misbehavior. However, this trend did not reach the conventional level of significance. Nevertheless, since 
previous research has shown that the effects of linguistic abstractness are subtle and difficult to detect in heterogeneous samples (Geschke, Sassenberg, Ruhrmann, \& Sommer, 2010; Graf et al., 2012), we found this preliminary observation encouraging for further investigation.

We decided to perform a second experiment aimed at identifying potential moderators of the effect of language abstractness on the intensity of collective emotions. Identification with a social group is perceived in research as a prerequisite of collective moral emotions (Wohl et al., 2006). More intense emotional reactions to more abstract versus more concrete language might be explained by the fact that highly abstract descriptions of negative behavior could more strongly affect the group perception as compared to concrete ones. If this is true, then the reactions to such information should be different among people highly and weakly identifying with that group.

\section{Experiment 2}

The main aim of Experiment 2 was to verify the effects of linguistic abstractness on eliciting emotional responses to ingroup members' misbehavior. We also wanted to explore the influence of the type of national identification (attachment vs. glorification; Roccas et al., 2006) on the relationship between linguistic abstractness and emotional reactions. Additionally, we expanded the number of scenarios used in the experiment (by adding two more situations to the scenarios from Experiment 1).

\section{Method}

Participants and procedure. A total of 116 German linguistics students (12 men, 104 women; $M_{\text {age }}=19.85, S D_{\text {age }}=2.47$ ) took part in the experiment. The participants were randomly assigned to one of four experimental conditions, where misbehavior of ingroup members was described using different levels of linguistic abstractness (DAV, IAV, ADJ, NOUN). First, all participants filled in the national identification scale (Roccas et al., 2006). Then, four scenarios were presented in which ingroup members misbehaved while being abroad. After each scenario, participants indicated how the story made them feel by indicating to what extent they experienced shame, guilt, anger, and regret.

Manipulation. The list of scenarios was extended in order to overcome the possible effects of a specific scenario content. Therefore, in addition to the two scenarios used in Experiment 1, we created two additional scenarios about a Polish driver who overtook other cars using a bus lane in Austria and about a Polish construction worker in the UK who was drunk at work (see Appendix). In order to pretest the materials we followed the same procedure as described in Experiment 1. The results revealed that the behaviors in the stories were perceived as creating a negative image of Poles $\left(M_{\text {Scenario3 }}=1.67, S D_{\text {Scenario3 }}=0.74\right.$; $\left.M_{\text {Scenario4 }}=1.44, S D_{\text {Scenario4 }}=0.60\right)$, as being negative $\left(M_{\text {Scenario3 }}=1.54\right.$, 
$\left.S D_{\text {Scenario3 }}=0.77 ; M_{\text {Scenario4 }}=1.21, S D_{\text {Scenario4 }}=0.41\right)$ and unfair $\left(M_{\text {Scenario3 }}=1.67\right.$, $\left.S D_{\text {Scenario3 }}=0.70 ; M_{\text {Scenario4 }}^{\text {Scenario4 }}=1.64, S D_{\text {Scenario4 }}^{\text {Scenario4 }}=0.87\right)$, and as happening sometimes $\left(M_{\text {Scenario3 }}=3.59, S D_{\text {Scenario3 }}=0.94 ; M_{\text {Scenario4 }}=3.68, S D_{\text {Scenario4 }}=0.84\right)$. All means differed significantly from the middle point of the scale $(p \mathrm{~s}<.001)$.

Measures. National identification. An eight-item scale (Roccas et al., 2006) measured the strength of national identification. Four items measured attachment to the national group (e.g. "I love Poland") and the other four items measures glorification of the national group (e.g. "Poland is better than other nations in all respects"). The answers were given using a scale from 1 (strongly disagree) to 7 (strongly agree). Both subscales were reliable ( $\alpha=.78$ and $\alpha=.71$, respectively). Collective moral emotions. Collective emotions were measured after each scenario using the same items and the same answer format as in Experiment 1. The composite measure, calculated as a mean of all four emotions for each of the four scenarios, was reliable in all cases (all $\alpha \mathrm{s}>.72$ ).

\section{Results}

As in the previous experiment, we were interested in the linear trend that indicates the influence of the level of linguistic abstractness on experiencing collective moral emotions. The experimental manipulation proved effective and the linear trend was significant in all four scenarios: $F_{\text {Scenariol }}(1,111)=14.87$,

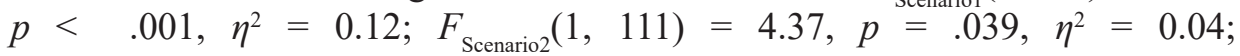
$F_{\text {Scenario3 }}(1,111)=6.31, p=.013, \eta^{2}=0.05 ; F_{\text {Scenario4 }}(1,111)=6.22, p=.014$, $\eta^{2}=0.05$. In all of them greater linguistic abstractness of the description was associated with experiencing more intense negative moral emotions. When the situations were combined, we observed that experimental manipulation proved effective and the negative emotions expressed by the participants significantly differed across conditions, $F(3,111)=3.58, p=.016, \eta^{2}=0.09$. The linear trend was significant, $F(1,111)=10.30, p=.002, \eta^{2}=0.08$, indicating that with growing abstractness of the negative behavior the negative emotions experienced by the participants intensified.

In order to explore the moderating influence of national identification (attachment and glorification) on the relationship between the linguistic abstractness of the description and the emotional responses, we ran two regression analyses: one with attachment and the other with glorification as moderators. Since the pattern of emotional reactions was the same across the four scenarios, we calculated the dependent variable as a mean of all negative emotions collapsed across all four situations $(\alpha=.91)$. Prior to the analyses, we centered the attachment and glorification measures and created the interaction terms for the level of abstractness and each type of national identification. The first model, with attachment as a moderator, was significant, $F(3,111)=4.14$, $p=.008, R^{2}=.10$, but the only significant predictor of the negative emotions was the level of abstractness, $\Delta R^{2}=.09, B=0.45, S E=0.16, p=.005$. Neither national attachment, $\Delta R^{2}=.02, B=0.27, S E=0.24, p=.27$; nor the interaction 


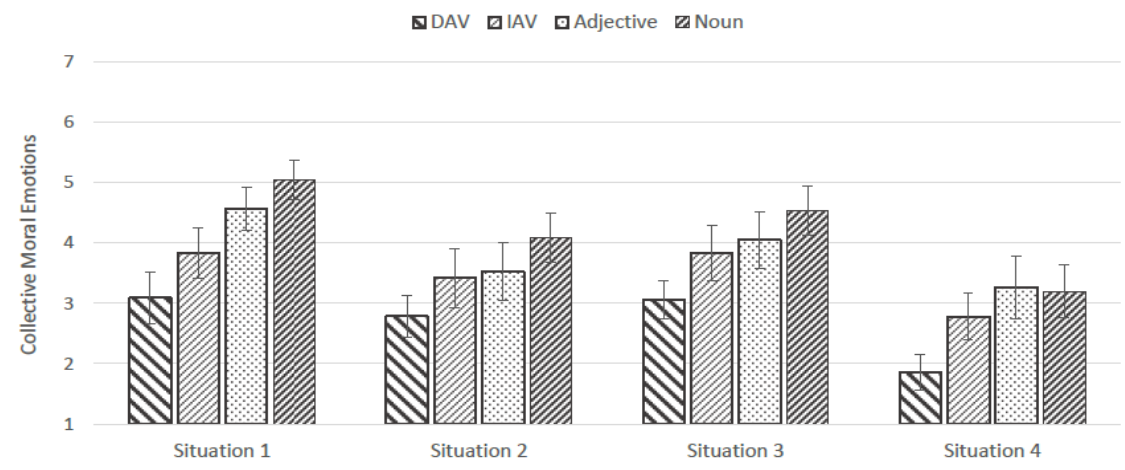

Figure 2. Means of the composite measure of negative collective emotions as a function of the abstractness of the description of negative ingroup behavior (DAV = Descriptive action verb; IAV = Interpretive action verb) across four situations (Situation 1 = abusing social system; Situation 2 = overtaking cars using bus lane; Situation 3 = drunk at work; Situation 4 = smuggling cigarettes). Error bars represent SEM.

of attachment and the level of abstractness, $\Delta R^{2}=.001, B=-0.04, S E=0.14$, $p=.79$, were significant. The results were similar with regard to the effects of glorification of one's nation. The model was significant, $F(3,111)=4.04$, $p=.009, R^{2}=.10$, but, again, the only significant predictor was the level of abstractness, $\Delta R^{2}=.09, B=0.48, S E=0.16, p=.002$. The effects of glorification, $\Delta R^{2}=.003 ; B=0.32, S E=0.25, p=.21$, and the interaction between glorification and abstractness, $\Delta R^{2}=.01, B=-0.16, S E=0.14, p=.26$, were both not significant.

\section{Discussion}

Experiment 2 replicated and strengthened the results of Experiment 1 by showing that the level of linguistic abstractness influenced the experience of negative emotions caused by negative behavior of ingroup members. We showed, using a broader range of situations, that when negative ingroup behavior is described in a more abstract way (i.e. using nouns rather than descriptive action verbs), it elicits more negative emotions. The hypothesized influence of national identification on the relationship between linguistic abstractness and negative emotions was not supported. Neither attachment to one's national group, nor glorification of that group proved to be significant predictors of negative collective emotions.

\section{General Discussion}

These two experiments demonstrated the small but systematic effects of linguistic abstractness on people's experience of collective moral emotions. In order to validate this effect, we performed a mega-analysis that jointly analyzed the pooled participant data from both studies. The dependent variable in 
both studies was equivalent - collective emotions induced by averaged situation did not differ, $t(275)=1.37, p=.14$. The joint analyses proved significant effect of linguistic abstractness on collective moral emotions across both studies, $F(1,273)=9.75, p=.002, \eta^{2}=0.03$. Information about ingroup members' misbehavior led to higher levels of collective moral emotions when expressed in the form of adjectives or nouns, and to lower levels of emotionality when expressed using verbs. Contrary to our expectations, the tendency to experience more negative emotions after being exposed to abstract depictions of negative ingroup behavior was not moderated by any form of national identification; neither by ingroup attachment, nor by ingroup glorification (Roccas et al., 2006).

Although we hypothesized that the effects of linguistic abstractness should be particularly visible among people who strongly identify with their group, one could also claim that high identification would block any emotional reaction to such information, by mobilizing denial rather than collective guilt. Research studying the effects of identification on collective moral emotions found that such emotions could not be observed among people with either the lowest or the highest levels of national identification (Klein, Licata, \& Pierucci, 2011).

We did not directly study the mechanism of the observed effects. However, according to LCM, the mechanism could be due to more internal attributions and stronger essentialising (e.g. Semin \& Fiedler, 1988; Wohl, Branscombe, \& Klar, 2006). After more abstract descriptions people might attribute the behavior more to the internal features of the ingroup members (i.e., they did it on purpose) rather than external features (i.e. the situation made them do it), and this can lead them to feel more negative emotions. Similarly, it could also be that after more abstract descriptions people think that the behavior shows who the person really is, that it says a lot about the person and also leads to more negative emotions. Both mechanisms are in line with theory, but we did not access them directly. Future research could fill in this gap and directly test the possible mechanisms behind the effects of abstractness on moral emotions.

The present research bridges the theoretical approach of the LCM (Semin $\&$ Fiedler, 1991) with analyses of collective moral emotions (Wohl et al., 2006). It suggests that language could affect effective communication about negative ingroup behaviors. These results may be useful for the political discourse on historical misdeeds (e.g. public apologies; Blatz \& Philpot, 2010; Philpot \& Hornsey, 2008), as they suggest that when politicians aim to elicit guilt or regret among their fellow ingroup members they should use more abstract linguistic terms.

Our research also suggests that linguistic abstraction could be used as an emotion-regulation strategy that allows for the downregulation of negative emotions such as collective guilt (Bilewicz, 2016; Goldenberg, Halperin, van Zomeren, \& Gross, 2016). Future research could analyze this process in greater detail, for example by looking at how people strategically tune down their abstraction levels when confronted with information about historical 
ingroup misbehavior, and how this in turn allows them to downregulate aversive moral emotions. Future research could also explore to what extent and under what circumstances the choice of abstraction levels is conscious and strategic, and when it is spontaneous and unconscious.

\section{Acknowledgements}

The research and the preparation of this article were funded by the National Science Center Sonata grant (2012/05/D/HS6/03431) and Beethoven grant (2014/15/G/HS6/04589).

Writing of this paper by Karolina Hansen was supported by the Foundation for Polish Science scholarship (START 030.2015-W).

\section{References}

Bilewicz, M. (2016). The dark side of emotion regulation: Historical defensiveness as an obstacle in reconciliation. Psychological Inquiry, 27, 89-95. doi:10.1080/1047840X.2016.1162130

Bilewicz, M., Witkowska, M., Stefaniak, A., \& Imhoff, R. (submitted). The lay historian explains intergroup behavior: Identification and epistemic abilities as correlates of ethnocentric historical attributions.

Blatz, C. W., \& Philpot, C. (2010). On the outcomes of intergroup apologies: A review. Social and Personality Psychology Compass, 4(11), 995-1007.

Branscombe, N. R., \& Miron, A. M. (2004). Interpreting the igroup's negative actions toward another group: Emotional reactions to appraised. In Harm. L. Z. Tiedens \& C. W. Leach (Eds.), The social life of emotions (pp. 314-335). New York, NY: Cambridge University Press.

Carnaghi, A., Maass, A., Gresta, S., Bianchi, M., Cadinu, M., \& Arcuri, L. (2008). Nomina sunt omina: On the inductive potential of nouns and adjectives in person perception. Journal of Personality and Social Psychology, 94(5), 839-859.

Center For Eurasian Studies Ankara (2016). The events of 1915 and the TurkishArmenian controversy over history. Retrieved from http://www.mfa.gov. tr/data/DISPOLITIKA/the-events-of-1915-and-the-turkish_armeniancontroversy-over-history-br.pdf

Doosje, B., \& Branscombe, N. R. (2003). Attributions for the negative historical actions of a group. European Journal of Social Psychology, 33(2), 235-248. doi:10.1002/ejsp.142

Doosje, B., Branscombe, N. R., Spears, R., \& Manstead, A. S. (1998). Guilty by association: When one's group has a negative history. Journal of Personality and Social Psychology, 75(4), 872-886.

Janoff-Bulman, R., Sheikh, S., \& Hepp, S. (2009). Proscriptive versus prescriptive morality: Two faces of moral regulation. Journal of Personality and Social 
Psychology, 96(3), 521-537.doi:10.1037/a0013779

Geschke, D., Sassenberg, K., Ruhrmann, G., \& Sommer, D. (2010). Effects of linguistic abstractness in the mass media. Journal of Media Psychology, 22, 99-104. doi:10.1027/1864-1105/a000014

Goldenberg, A., Halperin, E., van Zomeren, M., \& Gross, J. J. (2015). The process model of group-based emotion integrating intergroup emotion and emotion regulation perspectives. Personality and Social Psychology Review, 20, 118-141. doi:10.1177/1088868315581263

Graf, S., Bilewicz, M., Finell, E., \& Geschke, D. (2013). Nouns cut slices: Effects of linguistic forms on intergroup bias. Journal of Language and Social Psychology, 32(1), 62-83. doi:10.1177/0261927x12463209

Klar, Y., \& Branscombe, N. R. (2016). Intergroup reconciliation: Emotions are not enough. Psychological Inquiry, 27(2), 106-112. doi:10.1080/1047840X.2016.1163959

Klein, O., Licata, L., \& Pierucci, S. (2011). Does group identification facilitate or prevent collective guilt about past misdeeds? Resolving the paradox. British Journal of Social Psychology, 50(3), 563-572. doi:10.1111/j.20448309.2011.02028.x

Leach, C. W., Zeineddine, F. B., \& Čehajić-Clancy, S. (2013). Moral immemorial: The rarity of self-criticism for previous generations' genocide or mass violence. Journal of Social Issues, 69(1), 34-53. doi:10.1111/josi.12002

Kwiatkowska, A. (2013). Talking about violence: How people convey stereotypical messages about perpetrator and victim through the use of biased language. In R. Klein (Ed.) Framing sexual and domestic violence through language (pp. 87-109). New York, NY: Palgrave Macmillan. doi: 10.1057/9781137340092_5.

Lickel, B., Schmader, T., \& Spanovic, M. (2007). Group-conscious emotions: The implications of others' wrongdoings for identity and relationships. In J. L. Tracy, R. W. Robins, \& J. P. Tangney (Eds.), The self-conscious emotions: Theory and research (pp. 351-370). New York, NY: Guilford Press

Maass, A., Corvino, P., \& Arcuri, L. (1994). Linguistic intergroup bias and the mass media. Revue de Psychologie Sociale, 1(1), 31-43.

Maass, A., Salvi, D., Arcuri, L., \& Semin, G. R. (1989). Language use in intergroup contexts: The linguistic intergroup bias. Journal of Personality and Social Psychology, 57(6), 981-993.

Philpot, C. R., \& Hornsey, M. J. (2008). What happens when groups say sorry: The effect of intergroup apologies on their recipients. Personality and Social Psychology Bulletin, 34(4), 474-487. doi:10.1177/0146167207311283

Roccas, S., Klar, Y., \& Liviatan, I. (2006). The paradox of group-based guilt: Modes of national identification, conflict vehemence, and reactions to the in-group's moral violations. Journal of Personality and Social Psychology, 91(4), 698-711. doi:10.1037/0022-3514.91.4.698

Schmid, J., \& Fiedler, K. (1996). Language and implicit attributions in the 
Nuremberg trials analyzing prosecutors' and defense attorneys' closing speeches. Human Communication Research, 22(3), 371-398.

Schmid, J., \& Fiedler, K. (1998). The backbone of closing speeches: The impact of prosecution versus defense language on judicial attributions. Journal of Applied Social Psychology, 28(13), 1140-1172.

Semin, G. R. (2011). The linguistic category model. In P. A. M. Van Lange, A. Kruglanski, E. T. Higgins (Eds.), Handbook of theories of social psychology (Vol. 1, pp. 309-326). Thousand Oaks, CA: Sage.

Semin, G. R., \& Fiedler, K. (1988). The cognitive functions of linguistic categories in describing persons: Social cognition and language. Journal of Personality and Social Psychology, 54(4), 558-568.

Semin, G. R., \& Fiedler, K. (1991). The linguistic category model, its bases, applications and range. European Review of Social Psychology, 2(1), 1-30.

Vallacher, R. R., \& Wegner, D. M. (1987). What do people think they're doing? Action identification and human behavior. Psychological Review, 94(1), 3.

Walton, G. M., \& Banaji, M. R. (2004). Being what you say: The effect of essentialist linguistic labels on preferences. Social Cognition, 22(2), 193213. doi: $10.1521 /$ soco.22.2.193.35463

Wohl, M. J., Branscombe, N. R., \& Klar, Y. (2006). Collective guilt: Emotional reactions when one's group has done wrong or been wronged. European Review of Social Psychology, 17(1), 1-37. doi:10.1080/10463280600574815 


\section{Appendix}

Scenarios used in the experiments and their English translation. Experiment 1 used Scenarios A and B, and Experiment 2 used Scenarios A, B, C, and D.

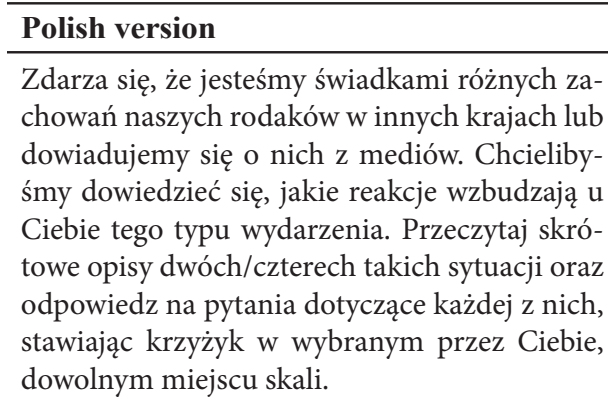

A. Niedawno $\mathrm{w}$ brytyjskiej prasie pojawiła się informacja o Polaku pracującym w Wielkiej Brytanii, który pobierał zasiłek dla najuboższych mimo swojej dobrej sytuacji materialnej.

Gdy myślisz o...

(DAV) Polakach, którzy w ten sposób pobierają zasiłek dla najuboższych w innych państwach,

(IAV) Polakach, którzy w ten sposób nadużywają systemu opieki społecznej w innych państwach (ADJ) takich Polakach, którzy są nieuczciwi (NOUN) takich Polakach-oszustach ...to w jakim stopniu odczuwasz.

Poczucie winy [0-1-2-3-4-5-6-7-8-9-10]

Wstyd

Żal

Gniew

B. W zeszłym miesiącu w niemieckiej gazecie „Der Spiegel” pojawiła się informacja o tym, że na granicy polsko-niemieckiej zatrzymano dwóch Polaków, którzy przewozili przez granicę papierosy w ilości większej niż dopuszczają to normy Unii Europejskiej.

\section{English translation}

Sometimes we witness various behaviors of our compatriots in other countries or we find out about them from the media. We would like to know what reactions these events trigger in you. Please read short descriptions of two/four such situations and answer questions related to each one by putting a cross on the scale in a place of your choice.

A. Recently British press wrote about a Pole working in the UK who was claiming social benefits for the poor despite his good financial situation.

When you think about...

(DAV) Poles, who are taking benefits for the poor in other countries (IAV) Poles, who abuse the social welfare system in other countries (ADJ) Poles who are dishonest (NOUN) Poles-cheaters ... to what extent do you feel...

Guilt [0-1-2-3-4-5-6-7-8-9-10]

Shame

Regret

Anger

B. Last month in a German newspaper "Der Spiegel", there was an information about two Poles who were arrested at the Polish-German border when they were transporting cigarettes in quantities exceeding the European Union regulations. 
Gdy myślisz o...

(ADJ) Polakach, którzy przewożą w ten sposób przez granicę papierosy...

(IAV) Polakach, którzy przemycają w ten sposób przez granicę papierosy

(ADJ) o takich Polakach, którzy są nieuczciwi (NOUN) takich Polakach-przemytnikach ...to w jakim stopniu odczuwasz...

C. Wyobraź sobie, że jesteś w Austrii i widzisz, że polski kierowca wjechał przed samochody stojące $\mathrm{w}$ korku, mijając je dzięki temu, że przejechał pasem zarezerwowanym dla autobusów.

Gdy myślisz o...

(DAV) Polakach, którzy w ten sposób wjeżdżają przed inne samochody na drogach w innych krajach...

(IAV) Polakach, którzy w ten sposób wpychają się przed inne samochody na drogach $\mathrm{w}$ innych krajach

(ADJ) takich Polakach, którzy są niekulturalni (NOUN) takich Polakach-piratach drogowych ...to w jakim stopniu odczuwasz...

D. W marcu 2010 roku podczas rutynowej kontroli przez Urząd ds. Higieny i Bezpieczeństwa Pracy okazało się, że Maciej Ś., Polak pracujący na budowie w Exeter, pił alkohol przed przyjściem do pracy.

Gdy myślisz o...

(DAV) Polakach pracujących za granicą, którzy piją alkohol przed pójściem do pracy... (IAV) Polakach pracujących za granicą, którzy upijają się przed pójściem do pracy

(ADJ) takich Polakach, którzy są nieodpowiedzialni

(NOUN) takich Polakach-pijakach ...to w jakim stopniu odczuwasz...
When you think about...

(DAV) Poles, who are transporting cigarettes through the border like that

(IAV) Poles, who are smuggling cigarettes through the border like that

(ADJ) Poles who are dishonest

(NOUN) Poles-smugglers

... to what extent do you feel...

C. Imagine you are in Austria and you see a Pole who, by driving on a bus lane, drove in front of other cars, which were stuck in traffic.

When you think about...

(DAV) Poles, who are driving in front of other cars like that in other countries

(IAV) Poles, who are cutting in front of other cars like that in other countries

(ADJ) Poles who are uncivil

(NOUN) Poles-roadhogs

... to what extent do you feel...
D. In March 2010 during a routine control by the Institute of Occupational Hygiene and Safety, it turned out that Maciej S., a Pole working on a construction site in Exeter, has been drinking alcohol before coming to work.

When you think about...

(DAV) Poles working abroad, who are drinking alcohol before going to work (IAV) Poles working abroad, who get drunk before going to work

(ADJ) Poles who are irresponsible

(NOUN) Poles-drunkards

... to what extent do you feel... 